\title{
Çalışma Sermayesi Etkinlik Ölçümünde Alternatif Bir Araç: İndeks Yöntemi*
}

\author{
Emine GÜLER** \\ Filiz KONUK ${ }^{* * *}$
}

\section{$\ddot{O Z Z E T}$}

Çalı̧̧ma, BiST'te işlem gören işletmelerin çalışma sermayesi etkinlik düzeyini, literatürde kullanılan yöntemlerden farklı bir yöntem olan indeks etkinlik yöntemiyle belirlemek amaciyla yapılmıştır. İşletmelerin, 2009-2016 yılları arasındaki etkinliklerinin ölçümü yapılmış ve yapılan analizler sonucunda 2 ve 21 kodlu işletmelerin dönen varlıklarındaki artış oranının satışlardaki artış oranına kıyasla daha düşük olduğu saptanmıştır. Dönen varlık hesap gruplarının ortalama performanslarına bakıldiğında ise 6 kodlu işletmenin en yüksek performansa sahip olduğu sonucuna ulaşılmıştır.

Anahtar Kelimeler: Çalışma Sermayesi, Etkinlik, İndeks Yöntemi, BiST.

JEL Sinıflandirması: G30, G10.

\section{An Alternative Tool In The Working Capital Efficiency Measurement: Index Method}

\section{ABSTRACT}

The study was carried out to determine the working capital efficiency level of the companies which are traded in BIST by the index efficiency method which is a different method from the methods used in the literature. The measurement of the efficiency of the companies between 2009 and 2016 was conducted by using the index method and as a result of the analyzes, it is concluded that the rate of increase in the current assets of the companies with 2 and 21 code is lower compared to the increase in sales. When the average performance of current asset groups, it is concluded that 6 code company has the highest performance.

Keywords: Working Capital, Efficiency, Index Method, Istanbul Stock Exchange.

Jel Classification: G30, G10.

Makale Gönderim Tarihi: 15.01.2019

Makale Kabul Tarihi: 21.03.2019

Makale Türü: Araştırma Makalesi

\footnotetext{
* Makale, hazırlanmakta olan doktora tezi kapsamında yapılan bir çalışmadır.

** Öğr. Gör., Bingöl Üniversitesi Sosyal Bilimler MYO, sauemineguler@ gmail.com, Orcid ID: 0000-0002-1823$162 X$.

*** Dr. Öğr. Üyesi, Sakarya Üniversitesi, İşletme Fakültesi, faygen@sakarya.edu.tr, Orcid ID: 0000-0003-0767$713 \mathrm{X}$.
} 


\section{GİRIŞ}

Rekabetin küresel boyutlara ulaştığı günümüz koşullarında sermayedarlar adına finansman ve yatırım kararları alan işletmeler için çalışma sermayesinin etkin bir şekilde yönetimi hayati önem taşımaktadır.

Çalışma sermayesi, işletmelerin günlük faaliyetlerini aksamadan gerçekleştirebilmeleri ve duran varlıklarını etkin bir şekilde çalıştırabilmek için ihtiyaç duydukları sermaye (Stoltz vd, 2007: 305) olarak tanımlanmaktadır.

Çalışma sermayesi yönetimi, cari varlıkların ve cari borçların etkin bir şekilde planlanması ve kontrol edilmesini, borçların ödenememe riskinin azaltılmasını ve cari varlıklara gereksiz yatırımların yapılmamasını ifade etmektedir (Eljelly, 2004). İşletmelerde etkin bir çalışma sermayesi için; finansal performansı arttıracak şekilde en uygun dönen varlık yapısının oluşturulması, nakit yetersizliklerinin yol açacağı risklerin minimize edilmesi ve finansman ihtiyaçları karşılanırken maliyetlerin en aza indirgenmesi amaçlanmaktadır. (Ata ve Buğan, 2016). Bu bağlamda işletmenin başarısı çalışma sermayesi unsurlarının etkin bir biçimde yönetimine bağlı olmakta ve bu başarı hissedarların refahını maksimize etme noktasında önemli bir rol oynamaktadır.

Çalışma sermayesinin yönetiminin ölçümünde kullanılan en yaygın ölçüt, nakit dönüş süresidir (NDS). NDS, “hammadde için yapılan nakit ödeme günü ile alacakların nakit olarak tahsil edildiği gün arasında geçen süre olup” (Moyer vd. 2007: 477) ATS (Alacak tahsil süresi), STS ve BÖS (borç ödeme süresi) olmak üzere üç ana bileşenden oluşmaktadır. NDS'nin kısa olması şirketler için olumlu olmakla beraber bu durum her zaman ve koşulda çalışma sermayesi yönetiminin etkinliğine işaret etmemektedir.

Literatürde, NDS kullanılarak çalışma sermayesinin etkinliğinin ölçüldüğü pek çok çalışma bulunmaktadır. Bu çalışmaların bir kısmında, çalışma sermayesi ve kârlılık ilişkisinin negatif; bir kısmında ise pozitif yönlü bir ilişkinin olduğu yönünde sonuçlara ulaşılmıştır. Araştırma literatüründe görülen bu ayrılık, bu ilişkinin niteliği konusunu belirsizleștirmektedir. $\mathrm{Bu}$ belirsizliği gidermek amacıyla bu çalışmada, etkinliğin NDS dışında farklı bir gösterge olarak etkinlik indeksi ile ölçülmesi amaçlanmıştır. Çalışma sermayesi etkinlik indeksi, performans ve kullanım indeksi olmak üzere iki alt unsurun çarpımından oluşan bir göstergedir. Performans indeksi, işletmelerin cari varlıkları içindeki çeşitli hesap kalemlerinin ortalama performanslarını ifade ederken; kullanım indeksi ise işletmelerin cari varlıkların kullanarak satış yaratma yeteneğini diğer bir ifadeyle dönen varlıklarını kullanma derecesini göstermektedir (Bhattacharya, 1997).

BİST’te işlem gören işletmelerin çalışma sermayesi etkinlik düzeyini ölçülmesinde etkinlik indeksinin kullanıldığı bir çalışmaya şu ana kadar rastlanılmamıştır. Bu bağlamda çalışmanın literatüre katkı sağlayacağı düşünülmektedir.

\section{LITERATÜR TARAMASI}

Çalışma sermayesinin etkinliğinin ölçüldüğü pek çok çalışma yapılmıştır. Bu çalışmalarda etkinlik ölçütü olarak daha çok NDS kullanılmakla birlikte etkinlik indeksinin kullanıldığı çalışmalar da söz konusu olmaktadır. 
Mathuva (2010), NDS'nin işletme kârlılığına etkisini incelemek için Nairobi Borsa'nda faaliyet gösteren 30 üretim işletmesinin verilerini kullanarak, panel veri yaptığ çalışmasında ATS ile kârlılık arasında önemli düzeyde negatif, STS ve BÖS ile kârlılık arasında ise güçlü düzeyde pozitif, NDS ile kârlılık arasında \% 10 anlamlılık düzeyinde negatif ilişki tespit etmiştir.

Gill, Biger ve Mathur (2010) işletme sermayesi yönetiminin kârlılık üzerindeki etkisini incelemek amacıyla New York Borsası'na kayıtlı 88 adet imalat işletmesine ait panel veri setini kullanmıştır. Çalışmada açıklayıcı değişkenler; alacak tahsil süresi, stok devir süresi, borç ödeme süresi ve nakit dönüşüm süresi olarak belirlenmiştir. Firma büyüklügüu, kaldıraç oranı ve duran varlık/toplam varlık oranı kontrol değişkenleri, brüt kârlılık ise firma kârlılığı göstergesi olarak belirlenmiştir. Panel veri analizi sonucunda firma kârlılığı ile alacak tahsil süresi arasında negatif ilişki tespit edilmiş, firma kârlılığı ile stok tutma süresi arasında ise istatistiksel olarak anlamlı bir ilişki saptanmamıştır. Nakit dönüşüm süresi ile brüt faaliyet kârı arasında pozitif ilişki tespit edilmiştir.

Dong ve Su (2010), Vietnam Borsasına kayıtlı işletmelerin 2006-2008 yılları verilerini kullanarak NDS ile brüt kârlılık arasındaki ilişkiyi araştırmıştır. Regresyon analizi aracılığıyla elde edilen bulgularda nakit döngüsü ile işletme kârlılığı arasında anlamlı bir negatif ilişki tespit edilmiştir.

Charitou vd.(2010), tarafından yürütülen araştırmada Kıbrıs Borsası'nda faaliyet gösteren işletmelerin 1998-2007 yıllarına ilişkin verileri kullanılarak çalışma sermayesi ve kârlılık ilişkisi incelenmiştir. Regresyon analizi sonucunda NDS ve alt bileşenleri ile aktif kârlılığı arasında ilişki tespit edilmiştir.

Sharma ve Kumar (2011), işletme sermayesi ve kârlılık ilişkisini Bombay Borsası'nda işlem gören 263 işletme üzerinde incelemiş̧tir. Finansal nitelikte olmayan işletmelerin 20002008 yılları arasındaki verileri kullanılarak çoklu regresyon analizi yapılmıştır. Analiz sonucunda BÖS ve STS ile kârlılık arasında negatif; ATS ve NDS ile kârlılık arasında pozitif ilişki tespit edilmiştir.

Singapur Borsası üzerinde yapılan bir araştırmada ise 94 işletmenin 2004-2011 yıllarına ilişkin 752 gözlemden oluşan panel veri seti kullanılarak çalışma sermayesi yönetiminin kârlılığı etkileyip etkilemediği araştırılmıştır. Araştırma kapsamında NDS, ATS ve SDS açıklayıcı değişken, aktif kârlılığı ise bağımlı değişken olarak belirlenmiştir. Ayrıca firma büyüklüğü, satışlarda büyüme oranı ve kaldıraç oranı kontrol değişkeni olarak kullanılmıştır. Panel veri analizi sonuçları, firma kârlılığı ile NDS uzunluğu arasında pozitif bir ilişki tespit edilmiştir. Söz konusu bulgulara ek olarak firma büyüklüğü ve satışlardaki büyüme arasında negatif ilişki görülmüştür (Mansoori ve Muhammad, 2012).

Abuzayed (2012), Amman Borsası'na kayıtlı 52 işletmenin çalışma sermayesi yönetimi ile kârlılıkları arasındaki ilişkiyi araştırmak amacıyla yaptığı çalışmada tobin q ve NDS ve bileşenlerini verisini kullanmıştır. Firma büyüklüğü, borç oranı ve satışlardaki değişim oranı verileri de kontrol değişkeni olarak belirlenmiştir. Panel veri analizinin uygulandığı araştırmada literatürle benzer olarak söz konusu işletmelerin NDS'si kısaltarak kârlılıklarını arttırabilecekleri sonucuna ulaşılmıştır. 
Napompech (2012) çalışmasında, brüt kâr marjı, NDS, ATS, STS ve BÖS değişkenlerini kullanarak çalışma sermayesi yönetiminin işletme performansını etkileyip etkilemediği sorusuna cevap aramıştır. Tayland Borsası'nda işlem gören yedi farklı sektörden 255 işletmenin 2007-2009 yıllarını kapsayan veri setine regresyon analizi uygulanmıştır ve NDS, ATS ve STS'nin kısaltılmasıyla kârlılı̆̆ın arttırılacağ sonucuna ulaşılmıştır.

Akoto vd. (2013), işletme sermayesi ve kârlılık ilişkisini Gana Borsası'na kayıtlı 13 üretim işletmesi üzerinde incelemiştir. Araştırmaya konu olan söz konusu işletmelerin 20052009 yıllarına ait panel veri seti kullanılmıştır. Çalışma kapsamında aktif kârlılığı bağımlı değişken, NDS, ATS, STS, BÖS ve cari oran bağımsız değişken olarak belirlenmiştir. Ayrıca firma büyüklüğü ve dönen varlık devir hızı ise kontrol değişkenleri olarak kullanılmıştır. Panel veri analizi sonucunda, NDS, cari oran, işletme büyüklüğü, dönen varlık devir hızı ile kârllılı arasında pozitif ilişki tespit edilmiştir.

Makori ve Jagongo (2013) çalışmalarında, Kenya'daki işletmelerin çalışma sermayesi yönetimi ve kârllıı ilişkisini araştırmıştır. Nairobi Borsası'nda işlem gören 5 imalat işletmesinin 2003-2012 yıllarına ait mali tablo verileri kullanılarak regresyon ve korelasyon analizi yapılmıştır. ATS ve NDS ile aktif kârlılığı arasında negatif, STS ve BÖS ile aktif kârlılı̆gı arasında ise pozitif yönlü bir ilişki bulunmuştur.

Yazdanfar ve Öhmen (2014), İsveç'de faaliyet gösteren KOBI'ler üzerinde çalışma sermayesi yönetimi ve kârlılık ilişkisini araştırmış̧ır. Dört farklı endüstri kolunda faaliyet gösteren 13.797 KOBİ'nin 2008-2011 dönemine ait verilerinin baz alındığ çalışmada aktif kârlılı̆ı bağımlı, NDS ve bileşenleri bağımsız, işletme büyüklüğü ve işletme yaşı kontrol değişkenleri olarak analize dahil edilmiştir. Regresyon analizi sonucunda NDS ile işletme kârlılı̆̆ arasında negatif ilişki, işletme büyüklügü̈, işletme yaşı ve kârlılık arasında da anlamlı negatif ilişki saptanmıştır.

Ukaegbu (2014), Afrika'da özellikle Misır, Kenya, Nijerya ve Kuzey Afrika'da faaliyet gösteren imalat işletmelerinin 2005-2009 yıllarına ait mali tabloları kullanarak firma kârlılı̆ı ile çalışma sermayesi yönetimi arasındaki ilişkiyi incelemiş̧tir. Çalışma sonucunda, net faaliyet kârı ve nakit dönüşs süresi ile kârllık arasında güçlü bir negatif ilişkinin olduğu ve nakit dönüş süresi arttığında firma kârlılığında düşüşün meydana geldiği görülmüştür

Thoa ve Nguyen (2014), HoChi City ve Hanoi borsasında işlem gören farklı sektörlerden 208 işletme üzerinde işletme sermayesi ve kârlllık ilişkisini test etmiştir. 20062012 dönemine ait verilere panel veri analizinin uygulandığ çalışmada NDS ve alt unsurları açıklayıcı değişkenler olarak belirlenirken, brüt kâr bağımlı değişken, işletme büyüklüğü, kaldıraç oranı ve cari oran kontrol değişkenleri olarak belirlenmiştir. Çalışmaya ilişkin analiz sonuçları brüt kârlııık oranı ile NDS, ATS ve STS arasında güçlü bir negatif ilişkinin varlığını kanıtlamıştır.

Angahar ve Alematu (2014), 2002-2009 dönemini kapsayan çalışmalarında Nijerya Borsası'na kayıtlı çimento imalatı yapan işletmelerin kârlılıkları üzerinde çalışma sermayesi yönetiminin etkili olup olmadığını araştırmışır. Araştırmada Nijerya Borsası'nda faaliyet gösteren 5 adet işletmenin mali tablo verileri aracıllğıyla çoklu regresyon analizi yapılmıştır. Çalışmanın değişkenleri; aktif kârlılı̆̆ı, NDS ve alt bileşenleri şeklinde belirlenmiştir. Analiz 
sonucunda ATS ile kârlılık arasında anlamlı olmayan negatif bir ilişki, NDS ile anlamlı pozitif bir ilişki olduğu tespit edilmiştir.

Yunos vd. (2015), çalışmalarında işletme performansı ve çalışma sermayesi ilişskisini araştırmıştır. Malezya'daki 58 kamu kurumu örnekleminde yapılan araştırma 2003-2014 yıllarına ait panel veri setini kapsamıştır. Çalışmada brüt kâr ve aktif kârlılığ sermayesi etkinlik göstergesi olarak NDS, ATS, STS ve BÖS bağımsız değişkenler olarak ele alınmıştır. Ayrıca firma büyüklügü, kaldıraç oranı ve satışlardaki büyüme kontrol değişkenleri olarak çalışmaya dâhil edilmiştir. Çalışmaya ilişkin bulgularda çalışma sermayesi ile aktif kârlılığı arasında ilişki tespit edilememiştir. Ancak brüt kâr ile BÖS arasında pozitif ilişki tespit edilmiştir.

Çakır (2013) işletme sermayesinin unsurları kapsamında firmaların nakit dönüşüm sürelerinin karlılıklarını etkileyip etkilemediği, etkiliyorsa yönü ve derecesinin ne olduğu araştırmıştır. Çalışmada BİST'te işlem gören ve imalat sektöründe faaliyet gösteren 52 işletmenin 2000-2010 dönemine ait veri setine kullanılarak panel veri analizi uygulanmıştır. Bağımlı değişken olarak devamlı sermaye kârlılığı, bağımsız değişkenler olarak nakit dönüşüm süresi, alacak tahsil süresi, stok dönüşüm süresi ve kısa vadeli borç ödeme süresi kullanılmıştır. Diğer taraftan, kontrol değişkenleri olarak aktif devir hızı ve toplam borç / öz sermaye oranı kullanılmıştır. Analiz sonucunda, imalat sanayi genelinde işletmelerin nakit dönüşüm süresini (NDS) artırarak kârlılıklarını artırabilecekleri ortaya çıkmıştır. Kimya ve taş alt sektörlerinde ise kârlılık ile NDS arasında ters yönlü bir ilişki bulunmuştur.

Kendirli ve Konak (2014), işletme sermayesi yönetimi ve firma performansı arasındaki ilişkiyi araştırmak amacıyla BİST Gıda ve İçecek Endeksinde yer alan 18 işletmenin 2008-2012 dönemlerine ait 5 yıllık muhasebe ve piyasa verileri kullanmıştır. Bağımlı değişken olarak performans ölçütleri; tobin q, aktiflerin kârlılığı ve öz sermayenin kârlılı̆̆ı olarak ele alınmıştır. Bağımsız değişkenler, işletme sermayesi yönetimi değişkenleri ve kontrol değişkenleri olarak iki ana grupta oluşturulmuştur: İşletme sermayesi değişkenleri: $\mathrm{ADH}, \mathrm{SDH}, \mathrm{BDH}$ ve NDS analize dâhil edilmiştir. Ayrıca, satışların büyüklüğ̈̈, kaldıraç oranı ve cari oran kontrol değişkenleri olarak seçilmiştir. NDS ve ADH ile aktif kârlılığı ve öz sermaye kârlılığı arasında negatif yönlü \%10 düzeyinde anlamlı bir ilişki bulunmuşken, tobin q açısından negatif ilişkinin istatiksel açıdan anlamlı olmadığı görülmüştür.

Demireli, Başcı ve Karaca (2014), işletme sermayesi unsurlarının sektörel kârlılığa etkisini araştırmak amacıyla Gayrimenkul Yatırım Ortaklıkları Sektörü, Madencilik Sektörü, Teknoloji Sektörü, Ticaret Sektörü ve İmalat Sektörü olmak üzere 5 sektörün 1998-2010 yıllarına ilişkin panel veri setini kullanarak analiz yapmıştır. Analize konu olan bağımlı değişkenler; aktif kârlılığı, öz sermaye kârlılığı, piyasa değeri/defter değeri ve tobin q, bağımsız değişkenler; alacak devir hızı, stok devir hızı, likidite oranı, kaldıraç oranı, cari yıl satışları ve dönen varlık/toplam aktifler olarak belirlenmiştir. Cari oran, kaldıraç oranı ve dönen varlık / toplam aktif değişkenleri, bağımlı değişken aktif kârlılığı ve öz sermaye kârlılığını açıklamada istatistiki açıdan anlamlı sonuçlar vermiştir. Piyasa değeri / defter değeri verisini açıklamada ise sadece satışlar değişkeni anlamlı olurken; tobin q verisini açıklamada da likidite oranı, cari oran ve satışlar değişkenleri istatistiki açıdan anlamlı olarak hesaplanmıştır. 
Aytürk ve Yanık (2015), araştırmalarında Türkiye'deki KOBİ'lerde çalışma sermayesi yönetiminin işletme kârlılığına olan etkisini test etmek amacıyla ORBİS veri tabanında yer alan Türkiye'deki 1.123 işletmenin 2009-2013 dönemine ait verilerini kullanmıştır. Dinamik panel veri analizi yönteminin kullanıldığı çalışmada brüt kâr ve faaliyet kârı bağımlı değişken, NDS ve alt unsurları ise bağımsız değişken olarak belirlenmiştir.

Toraman ve Sönmez (2015), 2009-2013 yıllarını kapsayan çalışmalarında BİST perakende ve ticaret sektöründe faaliyet gösteren 11 işletmenin mali tablolarından elde edilen verileri kullanmışlardır. Çalışma sermayesi yönetiminin kârlılık üzerindeki etkisini incelemek amacıyla brüt satış kârı ve ATS, STS, ticari borç devir süresi ve net ticaret süresi (NDS / satışlar) değişkenleri kullanılmıştır. Yapılan panel veri analizi sonucunda bağımsız değişkenlerin brüt satış kârı üzerinde herhangi bir etkisinin olmadığı sonucuna ulaşılmıştır

Keskin ve Gökalp (2016), 2009-2013 dönemini ele aldıkları çalışmalarında BİST gıda ve içecek sektöründe faaliyet gösteren ve ilgili dönemlerde verileri kesintisiz olan 17 işletmenin mali tablo verilerini kullanarak çalışma sermayesi yönetiminin kârlılık üzerine etkisini araştırmıştır. Çalışmada kârlılık göstergesi olarak aktif kârlılığı; NDS ve bileşenleri bağımsız değişken olarak panel veri analizinde kullanılmıştır. Ayrıca kurulan tesadüfi etkiler modelinin verileri açıklama gücünü ve güvenirlilik düzeyini artırması amacıyla cari oran, firma büyüklüğü ve kaldıraç oranı kontrol değişkenleri olarak belirlenmiştir. Panel veri analizlerinin sonucunda aktif kârlılığı ile NDS ve stok devir süresi arasında istatistiki olarak anlamlı olmayan negatif bir ilişki bulunmuştur. Çalışmada ATS ve kârlılık arasında negatif ve anlamlı bir ilişki; BÖS ile kârlılık arasında negatif yönlü ancak anlamsız bir ilişki bulunmuştur.

Fettahoğlu ve Mohamud (2016) çoklu regresyon analizini kullanarak çalışma sermayesi unsurları ile kârlılık arasındaki ilişkiyi incelemiştir. NDS ve alt unsurları bağımsız değişken, aktif kârlılığının ise bağımlı değişken olarak kullanıldığı çalışmada, 2009-2014 dönemi BISST'te işlem gören gida ve içecek şirketlerinin mali tablo verileri kullanılmıştır. Çalışmanın sonucunda ATS, STS ve BÖS ve NDS ile aktif kârlılı̆̆ı arasında anlamlı ve negatif yönlü bir ilişki tespit edilmiştir.

Literatürde çalışma sermayesi etkinlik indeks modeli kullanılarak Tahran, Pakistan ve Malezya' da gerçekleştirilen çalışmalar da bulunmaktadır.

Valipour ve Jamshidi (2012), çalışma sermayesinin etkinliği ile kârlılık arasındaki ilişkiyi Tahran Borsası'na kayıtlı dört farklı sektörden 72 imalat işletmesi üzerinde test etmiştir. Çalışmada faaliyet kârı bağımlı değişken; performans indeksi, kullanım indeksi, etkinlik indeksi ve NDS bağımsız değişken; borç oranı ise kontrol değişkeni olarak belirlenmiştir. Regresyon analizi sonucunda performans indeksi ve kullanım indeksi ile kârlılık arasında pozitif ilişki saptanmıştır. Bu bulgulara ek olarak kârlılık ile NDS arasında pozitif ancak istatistiksel açıdan anlamlı olmayan bir ilişki tespit edilmiştir.

Shehzad vd (2012), işletme sermayesi ve kârlılık ilişkisini Pakistan'daki Karachi borsasına kayıtlı tekstil işletmeleri üzerinde araştırmıştır. Faaliyet kârının bağımlı değişken olarak kullanıldığı çalışmada performans indeksi, kullanım indeksi, etkinlik indeksi ve NDS de bağımsız değişken olarak belirlenmiştir. Regresyon analizinin sonuçları çalışma sermayesi etkinlik düzeyi ile faaliyet kârı arasında anlamlı ilişski olduğunu göstermiştir. Ayrıca 
performans indeksi, kullanım indeksi ve etkinlik indeksi ile faaliyet kârı arasında pozitif ilişki tespit edilmiştir.

Kasiran vd. (2016), Malezya'da faaliyet gösteren 24 adet KOBI'nin çalışma sermayesi etkinlik düzeylerini araştırmıştır. 2010-2013 dönemini kapsayan araştırmada çalışma sermayesi etkinlik ölçümü aracı olarak etkinlik indeksi değerleri kullanılmıştır. Çalışma sonucunda yapılan istatiksel analizler orta büyüklükteki işletmelerin çalı̧̧ma sermayesi etkinlik düzeylerinin küçük işletmelere göre daha düşük olduğunu göstermiştir.

\section{VERİ, DEĞISSKENLER VE ANALİZ}

\subsection{Veri}

Çalışmada, BİST’te faaliyet gösteren ve çalışma periyodunda verileri süreklilik arz eden 21 işletmenin 2009-2016 yılları arasındaki çeyrek dönemlik bağımsız denetimleri tamamlanmış mali tablo verileri kullanılmıştır. Araştırmada kullanılan veriler Borsa İstanbul ve Kamu Aydınlatma Platformunun web sitelerinden elde edilmiştir.

\subsection{Değişkenler}

Araştırma kapsamında kullanım indeksi, performans indeksi ve etkinlik indeksi olmak üzere üç adet değişken kullanılmıştır. Performans indeksi (PI), işletmenin dönen varlıkları içindeki çeşitli hesap kalemlerinin ortalama performanslarını göstermekte ve araştırmaya konu olan her bir işletmenin dönen varlık alt hesap kalemlerinin performansını ölçmek için kullanılmaktadır. Çalışmada dönen varlıklar; nakit ve nakit benzerleri, ticari alacaklar, stoklar ve diğer dönen varlıklar olmak üzere dört ana grupta ele alınmıştır. Kullanım indeksi (UI), işletmenin dönen varlıklarını kullanarak satış yaratma kabiliyetini ölçmekte, diğer bir ifadeyle dönen varlıkların kullanım derecesini ifade etmektedir. Hem kullanım hem de performans indeksi değerlerinin birden büyük olması çalışma sermayesinin düzgün ve verimli bir şeklide yönetildiğini göstermektedir. Etkinlik indeksi (EI) ise, çalışma sermayesi etkinliğinin nihai göstergesidir, kullanım ve performans indeksinin çarpım değerini ifade etmektedir. Etkinlik indeksi değerinin birden büyük olması çalışma sermayesinin etkin yönetildiğini göstermektedir. Değişkenler ve hesaplamaları Tablo 1'de yer almaktadır. 
Tablo 1. Çalışma Sermayesi Etkinlik Ölçüm Değişkenleri

\begin{tabular}{|c|c|}
\hline Değişkenler & Hesaplamalar \\
\hline \multirow[b]{2}{*}{ PI } & $\mathrm{I}_{\mathrm{s}} \quad \sum_{\mathrm{i}=1}^{\mathrm{n}} \quad \mathrm{W}_{\mathrm{it}-1} / \mathrm{W}_{\mathrm{it}} / \mathrm{N}$ \\
\hline & $\begin{array}{c}\mathrm{I}_{\mathrm{s}}=\text { Satı̧̧lar }_{\text {cari dönem }} / \text { Satışlar }_{\text {önceki dönem }} \\
\mathrm{W}_{\mathrm{i}=\text { Dönen varlık alt hesap grubunun tutarı }} \\
\mathrm{W}_{\mathrm{it}=\mathrm{i} \text { şirketinin } \mathrm{t} \text { dönemindeki dönen varlık alt hesap grubunun tutarı }} \mathrm{N}=\text { Dönen varlık alt hesap grubu sayıs1 }\end{array}$ \\
\hline UI & $\mathrm{A}_{\text {önceki dönem }} / \mathrm{A}_{\text {cari dönem }} \quad(\mathrm{A}=$ Dönen Varlıklar / Satışlar $)$ \\
\hline EI & $\mathrm{PI} * \mathrm{UI}$ \\
\hline
\end{tabular}

Tablo 2'de indeks değerlerinin hesaplanma adımları uygulama örneği üzerinden detaylı bir şekilde gösterilmektedir.

Tablo 2. Araştırma Kapsamında Yer Alan Bir İşletmeye Ait İndeks Değerleri Uygulama Örneği

\begin{tabular}{|c|c|c|c|c|c|c|}
\hline & Satır Kodu & A & $\mathrm{B}$ & $\mathrm{C}$ & $\mathrm{D}$ & $\mathrm{E}$ \\
\hline $\begin{array}{l}\text { Sütun } \\
\text { Kodu }\end{array}$ & DÖNEM & $\begin{array}{l}20094 . \\
\text { Çeyrek }\end{array}$ & 2010 1. Çeyrek & 2010 2. Çeyrek & 2010 3. Çeyrek & 2010 4. Çeyrek \\
\hline 1 & $\begin{array}{c}\text { Dönen } \\
\text { Varlıklar } \\
\text { (TL) }\end{array}$ & 5.236 .716 & 3.437 .565 & 3.369 .290 & 3.005 .906 & 2.830 .677 \\
\hline 2 & $\begin{array}{c}\text { Nakit ve } \\
\text { Nakit } \\
\text { Benzerleri }\end{array}$ & 216.297 & 280.199 & 141.735 & 231.351 & 93.975 \\
\hline 3 & $\begin{array}{c}\text { Ticari } \\
\text { Alacaklar }\end{array}$ & 1.911 .634 & 421.262 & 565.624 & 878.890 & 150.194 \\
\hline 4 & Stoklar & 1.655 .046 & 1.479 .095 & 767.344 & 752.315 & 1.376 .920 \\
\hline 5 & $\begin{array}{c}\text { Diğer } \\
\text { Dönen } \\
\text { Varlıklar }\end{array}$ & 187.524 & 119.233 & 90.034 & 201.786 & 280.728 \\
\hline 6 & $\begin{array}{c}\text { Net Satışlar } \\
\text { (TL) }\end{array}$ & 16.351 .480 & 27.152 .582 & 40.068 .166 & 55.355 .546 & 23.916 .658 \\
\hline \multirow{2}{*}{7} & \multirow{2}{*}{$\begin{array}{c}\text { Kullanım } \\
\text { İndeksi } \\
\text { (UI) }\end{array}$} & & (A1/A6) & (B1/B6) & (C1/C6) & (D1/D6) \\
\hline & & & (B1/B6) & (C1/C6) & (D1/D6) & (E1/E6) \\
\hline
\end{tabular}




\begin{tabular}{|c|c|c|c|c|c|}
\hline 8 & $\begin{array}{l}\text { Performans } \\
\text { Índeksi } \\
\text { (PI) }\end{array}$ & $\begin{array}{c}(\mathrm{B} 6 / \mathrm{A} 6) *((\mathrm{~A} 2 / \mathrm{B} 2) \\
+(\mathrm{A} 3 / \mathrm{B} 3)+ \\
(\mathrm{A} 4 / \mathrm{B} 4)+ \\
(\mathrm{A} 5 / \mathrm{B} 5) / 4))\end{array}$ & $\begin{array}{c}(\mathrm{C} 6 / \mathrm{B} 6) *((\mathrm{~B} 2 / \mathrm{C} 2) \\
+(\mathrm{B} 3 / \mathrm{C} 3)+ \\
(\mathrm{B} 4 / \mathrm{C} 4)+ \\
(\mathrm{B} 5 / \mathrm{C} 5) / 4))\end{array}$ & $\begin{array}{c}(\mathrm{D} 6 / \mathrm{C} 6) *((\mathrm{C} 2 / \mathrm{D} 2) \\
+(\mathrm{C} 3 / \mathrm{D} 3)+ \\
(\mathrm{C} 4 / \mathrm{D} 4)+ \\
(\mathrm{C} 5 / \mathrm{D} 5) / 4))\end{array}$ & $\begin{array}{c}(\mathrm{E} 6 / \mathrm{D} 6) *((\mathrm{D} 2 / \mathrm{E} 2) \\
+(\mathrm{D} 3 / \mathrm{E} 3)+ \\
(\mathrm{D} 4 / \mathrm{E} 4)+ \\
(\mathrm{D} 5 / \mathrm{E} 5) / 4))\end{array}$ \\
\hline \multirow[t]{2}{*}{9} & $\begin{array}{c}\text { Etkinlik } \\
\text { Índeksi } \\
\text { (EI) }\end{array}$ & $\mathrm{B} 7 * \mathrm{~B} 8$ & $\mathrm{C} 7 * \mathrm{C} 8$ & D7*D8 & E7*E8 \\
\hline & \multicolumn{5}{|c|}{$\begin{array}{l}\text { B7 = 2,52 } \mathbf{B 8}=3,32 \quad \mathbf{C 7}=1,50 \quad \mathbf{C 8}=2,20 \quad \mathbf{D} 7=1,54 \quad \mathbf{D 8}=0,94 \quad \mathbf{E 7}=0,45 \quad \mathbf{E 8}= \\
1,03 \\
\text { (Performans ve kullanım indeksi değerleri virgülden sonra iki hane olacak şekilde tabloya yansıtılmıştır) }\end{array}$} \\
\hline
\end{tabular}

Tablo 2'deki referans değerler üzerinden hareketle Kullanım İndeksi (UI) değerleri için, söz konusu işletmenin 2010 yılının 1. çeyreğinde 2009 yılın 4. çeyreğine kıyasla toplam dönen varlık tutarının \%34 oranında azaldığını, buna karşın net satışların 2010 yılının 1. çeyreğinde 2009 yılın 4. çeyreğine kıyasla \%66 oranında arttı̆̆ı söylenebilir. 2010 yılının 2. çeyreğinde ise dönen varlıklar bir önceki çeyreğe göre \%1,98 azalırken satışlar \%47 artış göstermiştir. Aynı mantıkla diğer çeyrek dönemler için de açıklamalar yapılabilir.

Kullanım indeksi, bir işletmenin dönen varlıklarındaki artışa net satışlardaki artışın eşlik edip etmediği, ya da her iki unsurda artış veya azalış varsa hangi unsurun daha yüksek oranda artıp azaldığını dikkate alan bir göstergedir. Tablo 2'de, görüldüğü üzere kullanım indeksi çalışma sermayesi unsurlarının tamamını ele almaktadır. Dolayısıyla dönen varlıkları bütüncül bakış açısıyla ele alarak bu varlıkların etkin kullanılıp kullanılmadığını incelemektedir.

Performans indeksi ise biraz daha özele inerek dönen varlık alt hesap gruplarının bireysel olarak da etkin kullanılıp kullanılmadığını tespit etmeye çalışmaktadır. Bu bağlamda dönen varlıkları bir çalışma grubu gibi düşünecek olursak kullanım indeksi grubun toplam performansını baz alırken, performans indeksi ise grup üyelerinin tek tek bireysel performanslarını dikkate almaktadır.

Etkinlik indeksi ise nihai etkinlik indeksi göstergesi olup toplam çalışma sermayesi etkinliğini tek bir rasyo olarak ifade etmekte ve değerinin 1'den büyük olması işletmenin dönen varlıklarının etkin bir şekilde satış gelirleri yaratacak şekilde kullanıldı̆̆ 1 bilgisini içermektedir. Ayrıca bu indeks PI ve UI değerlerinin çarpımı şeklinde ifade edilerek hem grubun tamamının hem de bireysel olarak grup üyelerinin tek tek başarılı olmasını zorunlu kilmaktadır.

\subsection{Tanımlayıcı Analiz}

Tablo 3. BİST’te İşlem Gören İşletmelerinin Çalışma Sermayesi İndeks Değerleri (2009-2016)

$\begin{array}{cccccccccc}\begin{array}{c}\text { IŞSETME } \\ \text { Kod }\end{array} & \text { Mean } & \text { Min } & \text { Max } & \text { Mean } & \text { Min } & \text { Max } & \text { Mean } & \text { Min } & \text { Max } \\ 1 & 2.09 & 0.08 & 8.85 & 1.49 & 0.06 & 5.34 & 1.63 & 0.01 & 0.32 \\ 2 & 2.72 & 0.22 & 1.71 & 2.07 & 0.52 & 1.66 & 5.63 & 0.67 & 2.84\end{array}$




\begin{tabular}{lccccccccc}
3 & 1.50 & 0.22 & 3.65 & 1.32 & 0.23 & 2.25 & 2.47 & 0.05 & 8.04 \\
4 & 1.49 & 0.16 & 2.75 & 1.41 & 0.18 & 2.71 & 2.78 & 0.03 & 7.44 \\
5 & 2.16 & 0.17 & 14.57 & 1.35 & 0.23 & 3.25 & 3.92 & 0.05 & 0.84 \\
6 & 2.97 & 0.09 & 28.10 & 1.50 & 0.09 & 5.98 & 5.18 & 0.01 & 33.44 \\
7 & 1.65 & 0.18 & 3.38 & 1.39 & 0.20 & 2.77 & 2.94 & 0.04 & 9.02 \\
8 & 2.00 & 0.17 & 8.17 & 1.41 & 0.18 & 2.38 & 3.33 & 0.04 & 19.42 \\
9 & 2.86 & 0.21 & 10.30 & 1.30 & 0.20 & 2.35 & 4.23 & 0.07 & 20.17 \\
10 & 2.15 & 0.15 & 9.99 & 1.25 & 0.18 & 2.50 & 2.97 & 0.03 & 10.61 \\
11 & 2.33 & 0.14 & 14.14 & 1.51 & 0.14 & 3.37 & 5.09 & 0.02 & 43.11 \\
12 & 2.00 & 0.07 & 4.68 & 1.31 & 0.07 & 2.95 & 3.25 & 0.00 & 13.81 \\
13 & 1.45 & 0.14 & 3.43 & 1.31 & 0.19 & 2.32 & 2.34 & 0.03 & 5.71 \\
14 & 2.22 & 0.17 & 12.54 & 1.36 & 0.20 & 2.46 & 3.82 & 0.04 & 20.93 \\
15 & 2.04 & 0.22 & 11.73 & 1.31 & 0.23 & 2.36 & 3.51 & 0.05 & 25.49 \\
16 & 1.72 & 0.04 & 4.76 & 1.71 & 0.05 & 4.24 & 4.37 & 0.00 & 19.67 \\
17 & 2.32 & 0.20 & 14.44 & 1.28 & 0.24 & 2.30 & 3.52 & 0.05 & 30.37 \\
18 & 0.21 & 0.09 & 0.32 & 1.33 & 0.10 & 2.36 & 1.44 & 0.01 & 0.91 \\
19 & 1.22 & 0.18 & 2.72 & 1.29 & 0.20 & 2.12 & 1.88 & 0.04 & 5.63 \\
20 & 1.23 & 0.22 & 2.83 & 1.26 & 0.21 & 3.05 & 1.99 & 0.05 & 8.65 \\
21 & 2.72 & 1.84 & 1.86 & 2.07 & 2.24 & 1.50 & 5.63 & 4.12 & 2.80 \\
\hline & & & & & & & & &
\end{tabular}

Tablo 3, BİST’te işlem gören işletmelerin ortalama indeks değerlerini içermektedir. Kullanım indeksi değerlerine bakıldığında 2 ve 21 kodlu işletmelerin en yüksek (2.07) ortalama kullanım indeksi değerlerine sahip olduğu tespit edilmiştir. Tüm işletmelerin ortalama kullanım indeksi değerlerinin birden büyük olması işletmelerin dönen varlıklarında atıl bir kullanımın söz konusu olmadığını, dönen varlık artışlarının satışları desteklediğini göstermektedir. Dönen varlık alt hesap gruplarının ortalama performansını ifade eden performans indeksine bakıldığında ise 6 kodlu işletmenin en yüksek değere sahip olduğu, işletmenin kullanım indeksi değerinin de birden büyük (1.50) olduğu saptanmışır. Söz konusu işletmelerin hem dönen varlıklarının tamamını hem de dönen varlık alt hesap gruplarını ayrı ayrı başarılı bir şekilde kullanarak satış yarattı̆̆ı söylenebilir.

İşletmelerin toplam çalışma sermayesi etkinlik değerleri (EI) incelendiğinde 2 ve 21 kodlu (5.63) en yüksek değere sahip olduğu görülmektedir. Bu işletmelerin aynı zamanda en yüksek kullanım indeksi değerine sahip olduğu görülmüştür. 18 kodlu işletmenin ise çalışma periyodu içerisinde en düşük ortalama etkinlik indeksi değerine sahip olduğu görülmüştür.

\section{SONUÇ}

Çalışma BİST’te işlem gören işletmelerin çalışma sermayelerini verimli yönetip yönetmediklerini belirlemeye yönelik olarak gerçekleştirilmiştir. Benzer çalışmalardan farklı 
olarak çalışma sermayesi verimlilik göstergesi olarak NDS yerine Bhattacharya (1997) tarafından geliştirilen performans, kullanım ve etkinlik olmak üzere üç indeks değeri kullanılmıştır.

Yapılan analizler sonucunda, 2 ve 21 kodlu işletmelerin etkinlik indeksi (EI) değerlerinin en yüksek olduğu, 18 kodlu işletmenin en düşük indeks değerine sahip olduğu görülmüştür.

İşletmeler, çalışma sermayelerini kullanarak satış yaratma kabiliyetleri (UI) açısından değerlendirildiğinde 2 ve 21 kodlu işletmelerin diğer işletmelere kıyasla dönen varlıklarındaki artış oranına daha yüksek bir satış artış oranının eşlik ettiği tespit edilmiştir. Dönen varlık bireysel hesap gruplarının ortalama performanslarına (PI) bakıldığında ise 6 kodlu işletmenin en yüksek performansa, 18 kodlu işletmenin en düşük performansa sahip olduğu görülmüştür.

Sonuç olarak Borsa İstanbul'da faaliyet gösteren işletmelerin dönen varlık toplamını ve ayrı ayrı her bir alt hesap grubunu etkin yönetme noktasında performanslarının iyi durumda olduğu söylenebilir.

Araştırma indeks yönteminin Türkiye özelinde kullanıldığı öncü bir çalışma özelliği taşımaktadır. Genel olarak literatürde, çalışma sermayesi etkinliği ve karlılık ilişkisi ele alınmış ve aralarındaki ilişkinin yönü tespit edilmeye çalışılmıştır. Bu çalışmanın amacı ise işletmelerin etkinlik düzeylerinin farklı bir yöntem olan indeks yöntemiyle ortaya konması ile sınırlıdır. Gelecek çalışmalarda indeks değerlerinin farklı sektörler ya da alt sektörler için daha uzun periyotlar dikkate alınarak hesaplanmasının faydalı olacağı düşünülmektedir.

\section{KAYNAKLAR}

Abuzayed, B. (2012), "Working Capital Management and Firms' Performance in Emerging Markets: The Case of Jordan", International Journal of Managerial Finance, 8(2), pp. 155-179.

Akbulut, R. (2011), “İMKB'de İmalat Sektöründeki İşletmelerde İşletme Sermayesi Yönetiminin Kârlılık Üzerindeki Etkisini Ölçmeye Yönelik Bir Araştırma”, İstanbul Üniversitesi İşletme Fakültesi Dergisi, 40(2), ss.195-206.

Akoto, R. K. - Awunyo-Vitor, D. - Angmor, P. L. (2013), Working Capital Management and Profitability: Evidence from Ghanaian Listed Manufacturing Firms, 5(9), pp.373-379

Aksoy, Emine E. (2013), “İşletme Sermayesi Yönetimi ile Firma Performansı İlişkisi: 2008 Krizi Örneği”, Finans, Politik ve Ekonomik Yorumlar Dergisi. 50(586), ss. 9-21.

Angahar, P. A. - Alematu, A. (2014), "Impact of Working Capital on The Profitability of The Nigerian Cement İndustry", European Journal of Accounting Auditing and Finance Research, 2(7), pp. 17-30.

Ata, H. A. - Buğan, M. F. (2016), "İmalat Şirketlerinde Çalışma Sermayesi Etkinliğinin Firma Değerine Etkisi Nasıldır?” Selçuk Üniversitesi Sosyal Bilimler Enstitüsü Dergisi, (35), ss. 25-33. 
Aygün, M. (2012), "Firma Performansı Üzerinde Çalışma Sermayesinin Etkisi: Türk İmalat Sektörü Üzerine Bir Uygulama”, Ege Akademik Bakış Dergisi, 12(2), ss. 215-223.

Aytürk, Y. - Yanık, S. (2015), “Çalışma Sermayesi Yönetimi Türkiye'deki KOBİ'lerde Kârlılı̆̆ı Nasıl Etkiler?” Muhasebe ve Finansman Dergisi, (68), ss. 157-168.

Bhattacharya, H. (1997), Total Management by Ratios, Sage Publications, New Dehli.

Charitou, Melita Stephanou - Maria, Elfani - Petros, Lois (2010), “The Effect of Working Capital Management on Firm's Profitability: Empirical Evidence from an Emerging Market”, Journal of Business \& Economics Research, 8(12), pp. 63-68.

Çakır, H. M. (2013), "Nakit Döngüsünün Firma Kârlılı̆̆ına Etkisinin Sektörel Analizi”, Journal of Yaşar University, 8(30), ss. 4948-4965.

Demireli, E. - Başc1, E. S. - Karaca, S. S. (2014), "İşletme Sermayesi ve Performans Göstergeleri Arasındaki İlişkiler: Borsa İstanbul Üzerine Bir Uygulama”, Ege Stratejik Araştırmalar Dergisi, 5(1), ss. 79-98.

Dong, Huynh Phuong - Jyh-tay, Su (2010), “The Relationship between Working Capital Management and Profitability: A Vietnam Case", International Research Journal of Finance and Economics", (49), pp. 59-67

Fettahoğlu, Sibel - Mohamud, Fuaad Ahmet (2016), "Çalışma Sermayesi Yönetiminin İşletme Kârlılığı Üzerine Etkisi: BİST’de Bir Uygulama”, Elektronik Mesleki Gelişim ve Araştırma Dergisi, 4(2), ss. 16-28.

Eljelly, A. M. (2004), "Liquidity-Profitability Trade off: An Empirical İnvestigation in an Emerging Market", International Journal of Commerce and Management, 14(2), pp. 48-61.

Gill, A. - Biger, N. - Mathur, N. (2010), "The Relationship Between Working Capital Management And Profitability: Evidence From The United States", Business And Economics Journal, 10(1), pp. 1-9.

Karaduman, H. A. - Akbaş, H.E. - Özsözgün, A. - Durer, S. (2010), “Effects of Working Capital Management on Profitability: The Case For Selected Companies in The İstanbul Stock Exchange (2005-2008)". International Journal of Economics and Finance Studies, 2(2), ss. 47-54.

Kasiran, F. W. - Mohamad, N. A. - Chin, O. (2016), "Working Capital Management Efficiency: A Study on The Small Medium Enterprise in Malaysia", Procedia Economics and Finance, 35, pp. 297-303.

Kendirli, S. - Konak, F. (2014), "İşletme (Çalışma) Sermayesi Yönetiminin Firma Performansı Üzerindeki Etkisi: BİST Gıda, İçecek Endeksi Uygulaması”, Akademik Bakış Dergisi, 41(3). 
Keskin, R. - Gökalp, F. (2016), "Çalışma Sermaye Yönetiminin Firma Kârlılığı Üzerine Etkisi: Panel Veri Analizi”, Doğuş Üniversitesi Dergisi, 17(1), ss. 15-25.

Makori, D. M. - Jagongo, A. (2013), "Working Capital Management and Firm Profitability: Empirical Evidence from Manufacturing and Construction Firms Listed on Nairobi Securities Exchange", Kenya. International Journal of Accounting and Taxation, 1(1), ss. $1-14$.

Mansoori, D. E. - Muhammad, D. (2012), “ The Effect of Working Capital Management on Firm's Profitability: Evidence from Singapore", Interdisciplinary Journal of Contemporary Research in Business, 4(5), pp. 472-486.

Mathuva, D. (2010), “The İnfluence of Working Capital Management Components on Corporate Profitability: A Survey on Kenyan Listed Firms", Research Journal of Business Management, 4(1), pp. 1-11.

Moyer, R.C. - McGuigan, J.R. - Rao, R.P. (2007), Fundamentals of Contemporary Financial Management, Thomson South-Western College Publisher, USA.

Napompech, K. (2012), "Effects of Working Capital Management on the Profitability of Thai Listed Firms", International Journal of Trade, Economics and Finance, 3(3), pp. 227.

Qayyum, A. - Bolda, M. A. (2010), "Working Capital Management and Corporate Performance of Manufacturing Sector in Pakistan", International Research Journal of Finance and Economics, 47(1), pp. 151-163.

Saldanlı, A. (2012), "Likidite ve Kârlılık Arasındaki İlişki-İMKB 100 İmalat Sektörü Üzerine Ampirik Bir Çalışma", Süleyman Demirel Üniversitesi Sosyal Bilimler Enstitüsü Dergisi, 2(16), ss. 167-176.

Sharma, A. K. - Kumar, S. (2011), "Effect of Working Capital Management on Firm Profitability: Empirical Evidence from India”, Global Business Review, 12(1), pp. 159-173.

Shehzad, F. - Ahmed, K. - Sehrish, S. - Saleem, F. - Yasir, M. (2012), "The Relationship between Working Capital Management Efficiency and Ebit: Evidence from Textile Sector of Pakistan", Interdisciplinary Journal of Contemporary Research in Business, 4(5), pp. 211-224.

Stoltz, A. - Viljoen, M. - Gool. S. - Cronje, R. (2007), Financial Management: Fresh Perspectives, Cape Town: Pearson Education: Pearson/Prentice Hall, South Africa.

Toraman, C. - Sönmez, A. R. (2015), "Çalışma Sermayesi ve Kârlılık Arasındaki İlişki: Perakende Ticaret Sektörü Üzerine Bir Uygulama”, Erzincan Üniversitesi Sosyal Bilimler Enstitüsü Dergisi, 8(1), ss. 15-24.

Tu, T. T. - Nguyen, U. T. (2014), "Relationship Between Working Capital Management And Profitabilit Empirical Evidence From Vietnamese Listed Firms", International Conference on Finance And Economics (ICFE), 2-4 June, Vietnam, pp. 731-740. 
Valipour, H. - Jamshidi, A. (2012), "Determining the Optimal Efficiency İndex of Working Capital Management and İts Relationship with Efficiency of Assets in Categorized Industries: Evidence from Tehran Stock Exchange", Advances in Management and Applied Economics, 2(2), pp. 191-209.

Yazdanfar, D. - Öhman, P. (2014), "The İmpact of Cash Conversion Cycle on Firm Profitability: An Empirical Study Based on Swedish Data", International Journal of Managerial Finance, 10(4), pp. 442-452.

Yunos, R. M. - Nazaruddin, N. - Ghapar, F. A. - Ahmad, S. A. - Zakaria, N. B. (2015), "Working Capital Management in Malaysian Government-Linked Companies, Procedia Economics and Finance, 31, pp. 573-580. 